\title{
Exploring Gaps Associated with Gender Empowerment in Selected African Countries
}

\author{
Prof. S. M Kang'ethe \\ University of Fort Hare, Department of Social Work and Social Development, \\ Private bag X1314, ALICE. 5700, South Africa \\ Email: skangethe@ufh.ac.za \\ Shylet Yvonne Chivanga \\ Department of Development Studies \\ Email: 200909964@ufh.ac.za
}

Doi:10.5901/mjss.2014.v5n27p870

\section{Abstract}

Incontrovertibly, gender empowerment process continues to suffer immense gaps that if not timeously addressed can impede most countries to make significant scores in the 2015 Millennium Development Goal number three. The aim of this article is, through literature review methodology, to explore gaps associated with gender empowerment. Findings indicate the following factors that underpin gender empowerment process: Inadequate political participation; high rate of women unemployment; gender skewed health policies; cultural factors; women's inferiority complex; few women in managerial positions; countries meagre resources to invest in gender empowerment process; and increased cases of domestic violence. The article recommends: mainstreaming gender equality and equity policies; women to be united and stand for their rights; closing of the gender parity gap and working to make cultures both gender neutral and gender sensitive.

Keywords: Human rights, discrimination, policy, gender mainstreaming, gender analysis, gender equity, Millennium Development Goal number three.

\section{Problem Statement}

Although realistically the global world is treading, though at a lagged out process, towards realising the desirable and globally cherished state of gender equity and equality in a bid to make meaningful scores in the Millennium Development Goal number three, it is these researchers' contention that the phenomenon is still a mirage and exists more in the form of lip service than in practical terms. This is because the reality on the ground suggests immense gender gaps such as the violation of women's rights, discrimination in various forums such as in the job market, and their structural involvement in less productive work than their male counterparts. These scenario are glaring despite the dominant recognition of gender based policies and their domestication in many countries of the globe (Ricardo et al, 2012:14).

Realistically and unfairly, many nations continue to be men centred with gender responsiveness being only on paper. Irrefutably, development cannot be meaningful as long as gender gaps continue to take toll. The state is definitely detrimental to economic development and to the well- being of women. Realistically, gender gaps are disastrous to women empowerment generally and efforts to close them are desirable if women are to achieve their rights, more so their economic rights. It is therefore pertinent that the government and all development practitioners, as well as the researchers agree to have a serious autopsy of their countries' development structures and make a serious analysis of how they contribute to the gender gaps and make efforts to fill in such gaps.

In these researchers' thinking all development structures must competitively and fairly enlist women participation and involvement. This may mean realigning national and societal structures to allow women empowerment paradigm. They also have a feeling that implementation of half-hearted gender policies in many African countries for example, which directly or indirectly marginalise women empowerment remains an obstacle to meaningful gender equity. The outcomes of not addressing gender gaps are likely to further perpetuate perfidious results which are further likely to wreak havoc to human development in general and women in particular. Importantly, serious gender gaps need to be filled in social and economic development if meaningful human development is to be achieved. 


\section{Methodology}

This article has used document analysis. Document analysis is whereby the study uses facts or information which is already there and may have been used for other purposes (Shepherd, 2002:44). Text books, internet sources, government records, newspapers, education websites, journals and reports have been used to explore how national and societal structures have contributed to marginalising women. Document analysis has been used because it is inexpensive in the sense that it uses readily available information at little or no cost (Pizzaro \& Bartels, 2011: 57).

\section{Introduction and Background}

Despite increased awareness and activities to achieve women and girl child empowerment, gender gaps are still huge. Realistically, women are still ensnared in discrimination, domestic violence, and are voiceless in major decision making, are denied equal economic opportunities and have been driven to the state of increased poverty (Kang'ethe \& Mafa, 2014). They therefore suffer immense state of feminization of poverty and today as HIVIAIDS take toll in many African countries, women suffers the state of feminization of HIVIAIDS (Barnett \& Whiteside, 2006; Kang'ethe, 2013a, 2014a; Kang'ethe \& Munzara, 2014). One of the glaring causes of women disempowerment is their state of unemployment. For example in Sub Sahara Africa, about $70 \%$ of the women are underemployed and unemployed, $60 \%$ do not have tertiary education and they constitute 60\% of the HIV infected population (UNDP report, 1998:73; Ramphele, 2008; Barnett \& Whiteside, 2006).

Although the gaps pertaining to women empowerment are still at large, some international, regional and national policy environment have been a panacea as far as advocating for women empowerment is concerned. For instance, the Universal Declaration of Human Rights, 1948, Convention on the Elimination of all Forms of Discrimination Against Women (CEDAW), 1981, Convention on the Political Rights for Women, African Charter on Human and People's Rights, Beijing Platform of Action, 1995 and Millennium Development Goals have been strong policy pillars for driving gender policy empowerment in many countries of the world. To indicate the global community's leadership to tackle the challenge posed by gender inequality and inequity, the World bank set aside \$31billion for gender in 2013 and in 2011 \$US 20 billion was contributed for gender empowerment by OECD countries (Klugman and Morton, 2013:123).

South Africa has even gone further to effectuate women empowerment process on the ground with the ruling African National Congress (ANC) legislating that $50 \%$ of its seats go to women. However, there are dynamics such as their electability to parliament by the electorate. It is also good to recognize that the phenomenon of gender equity and equality are richly grounded in section 9 of the country's constitution (Republic of South Africa, 2013). The constitution guarantees everyone the right to equality and prohibits unfair discrimination against women and gender violence (Republic of South Africa, 2013). In addition, the employment equity Act of 1998 also inhibits unfair discrimination of all people including women in terms of employment. Further, the women empowerment and the gender equality bill advocates for women's empowerment in terms of education and skills development and reproductive health. In addition, it inhibits discrimination of women and gender based violence and postulates that at least $50 \%$ of decision making posts should be given to women (Botman, 2014). Perhaps it is good to show how South Africa has been loyal to the women empowerment paradigms. For example today, $44 \%$ of the cabinet is women. This move has made South Africa to be among the first ten countries for considering women in leadership positions (Botman, 2014).

However, increased women representation and women empowerment have not been a commensurate process. This is because only $20 \%$ of women are found in the top management at work places. This implies that the higher the position becomes the lower the number of women in such positions and the lower the position the higher the number of women in such position. It has been found that other African countries such as Zimbabwe, Ghana, Kenya, Nigeria, Tanzania, Malawi Mozambique and Zambia are not immune to this problem. This has increasingly informed the state of feminization of poverty (Kang'ethe 2013a). In Nigeria, for example, 70\% of the poor people are women (Ugwueje, 2013:186). However, the situation in South Africa of having fewer women at the top of organizations and leadership sharply contrasts with the country of Botswana, where although very few women are in parliament, women hold more than $52 \%$ of middle level management posts. However, it also needs be pointed out that even in the case of Botswana, women tend to be crowded in the low ranking jobs, the so labelled as 'women's jobs' especially the clerical ones (Maundeni, 2005). This implies that leadership structures and the employment laws and guidelines have been gender friendly (UNDP, 2004).

The fact that gender gaps are narrowing with time cannot be disputed especially in countries where gender gaps were very wide. However, the lion's share of development in many poor countries still remains in the hands of men at the expense of women. Perhaps the patriarchal systems and therefore socialization based on them could constitute a major 
reason for that (Kang'ethe, 2009). This paper views issues of women being undermined in many fronts such as in the global MDGs. For instance although there are eight Millennium Development Goals, but only development goal number 3 and number 2 are dedicated to deal with gender. This paper contends that all the eight goals should richly integrate the gender components as a way of gendering the whole fray of countries' development. However, these are options that can be considered after the 2015 as gender development and empowerment need to be an integral component of the global community and livelihood in general (Ugwueje, 2013).

\section{Gender Gaps}

\subsection{Nadquate political participation of women}

About 52\% of the world's population is women. However, they are the least represented in politics (Mupfeka, 2008:19). The gender political participation gap across the globe is 80\% (Klugman and Morton, 2013:124). The gap can only be solved if women take action and participate in decisions that affect their lives (Maundeni, 2005; Greisler, 2006). Even if good policies are put in place and as long as women are not involved in crafting and contributing to such policies, women's development and therefore their growth will always lag behind that their male counterparts (Maundeni, 2005; Greisler, 2006). In the same measure, the process of gender equality and equity will remain dwarfed no matter how much resources are invested to support gender equity and equality. Perhaps the country of Botswana can provide good examples. Although the country has been overly committed to gender empowerment, women's paltry involvement and participation in politics has slowed down women's gender empowerment process hugely (Maundeni, 2005; Greisler, 2006; UNDP, 2008).

Perhaps this is why the former President of Botswana, Festus Mogae during his tenure as the head of state earnestly urged women to consider voting their fellow women. However, this has not borne great dividends with less than $10 \%$ of the women being voted to both the civic and parliamentary seats in the country. This does not meet the aspirations of the SADC countries to have at least $30 \%$ civic and parliamentary seats go to women (SADC Gender Protocol, 2008). Regrettably, this lowered political participation and involvement is a characteristic of many Southern African countries such as Zambia and Namibia (Geisler, 2006). These researchers contend that African countries should learn from South Africa with $44 \%$ of its cabinet being women (Botman, 2014).

These researchers need to point out that although men have been a force to reckon with in pursuance of liberation movement, women have participated as supporters and collaborators. During the pre-colonial era in Africa, some women were a force to reckon with. For instance, the Zulu Kingdom in South Africa, Ganda in Uganda, Umuada women in Nigeria, a woman called Mbuyanehanda in Zimbabwe and Ashante women in Ghana participated in politics in the precolonial error (Selebogo and Ojakorotu, 2013:5178). However, even in instances where women fail to be very conspicuous, they have always offered unwavering support to men. They should therefore be given credit and not be relegated to the periphery of the mainstream political domain (Maundeni, 2005). Although many developing countries are the ones lagging behind as far as women empowerment is concerned, many countries of the developing part of the world have domesticated pertinent international gender empowerment policies to suit their circumstances. For example Botswana has crafted its own Millennium Development Goals. This is to guide the country in its road and terrain to achieve them before the hour of reckoning, which is 2015 (UNDP, 2004).

\subsection{Gaps pertaining to employment}

Though women are increasingly being accorded opportunities to employment in equal measure with men is some countries such as Botswana and South Africa, the equality and equity gap still exists. In some countries, the gap is very wide. This therefore can be interpreted as discrimination of women on grounds of gender (UNDP, 2008). This is not withstanding the fact that education of women has improved significantly (Ricardo et al, 2012:14). For example women work in low quality informal and less profitable jobs as compared to men. In addition, they work in unpaid family employment such as peasant agriculture, taking care of the elderly, the sick and the children (Kang'ethe, 2011). Even if they get employed, women have to balance between paid employment and the unpaid employment at home. This is because most of the household chores such as bathing the children, cooking are of critical importance for livelihood. The unfortunate state of affairs is that the household chores and tasks suffer serious gender bias, with the women usually left to handle almost 90 to $100 \%$ of the tasks. This presents gender exploitation, gender bias, gender oppression, and gender role demarcation, all factors gravitating towards weighing down the process of attaining gender equality and gender equity (Kang'ethe, 2009, 2011). This is despite the fact that both the husband and the wife may be working. In some 
extreme cases, the woman has to come home to handle most of the chores even if the husband may not be working (Chen ,2008:2).

Though unemployment respects no gender, it is high among women as compared to men. While $70 \%$ of men in the Sub Saharan Africa are unemployed, 85\% of the women are unemployed. In North Africa, 55\% of the women are unemployed compared to $32 \%$ of the men. In Middle East, $42 \%$ of the women are unemployed as compared to $27 \%$ of the men. In terms of retrenchment, women are the most victims of the circumstances. For example during the 2008 global economic crisis, it was two thirds of women who lost their jobs across the globe yet women constitutes only one third of the working class (ILO, 2012:11-34). Apparently, therefore, the world appears to be harsh to women than men. This could explain the preponderance of women poverty or the so called feminization of poverty (UNDP, 2008; Kang'ethe 2013a; Kang'ethe \& Munzara, 2014). This feminization of poverty has to a larger extent informed and influenced the state of the feminization of HIVIAIDS especially in many African countries (Kang'ethe, 2014a,b).

\subsection{Unequal health policies}

Some health policies presents a serious state of gender bias. For example the policy of testing pregnant women make women feel discriminated by it in that it does not obligate the testing of the man who was also involved in the generation of the child. The policy is therefore skewed and promotes gender discrimination, oppression and unfairness (Kang'ethe 2009). Perhaps this is why in many African countries more women than men know their status. This has put the HIVIAIDS campaign in jeopardy. Bearing in mind that men are perfect transmitters of the virus than women, and are five times more promiscuous than women, their lowered response to HIVIAIDS testing is a fertile ground for viral proliferation that has largely contributed to the state of feminization of HIVIAIDS (Barnett \& Whiteside, 2006; Ramphele, 2008;Kang'ethe, 2009, 2014a,b). Currently women in Sub Sahara Africa hold's a lion's share of the epidemic, with $60 \%$ of the women being infected (USAID,2012:7). Perhaps the governments of various countries should see this glaring gap in the policy and use all the possible interventions to have the men tested the same way as their women/wives. This can lower the gender gap in this respect.

\subsection{Cultural factors undermining the gender empowerment paradigms}

Incontrovertibly, cultural attitudes, cultural practices, cultural thinking and dispensation continue to derail the processes of gender empowerment and equity. This is perhaps because culture informs people's thinking, do's and dont's (Kang'ethe, 2009). Due to patriarchy in most African countries, for example, that make men to think that they are strong and should not easily seek medical interventions, this thinking and dispensation has made them to inadequately get involved in HIVIAIDS reponses, leaving women alone to respond (Kang'ethe, 2009; Lekoko, 2009). Due to cultural obligation and demands that women need to be submissive, in most cases they fail to negotiate for the use of contraceptives such as condoms, or make good arguments when men become unfaithful to them. Patriarchy has a negative effect in the relationship because it condones skewed power relationship with men holding the lion's share of the power. Women in some cases have become sexual slaves. The situation becomes perfidious when upon the discovery that their husbands are HIV positive, they remain passive and gullible since cultures teach women to be submissive to their husbands. Cultures, in this respect becomes a blackmailing and oppressive agency. This also explains the environment of viral proliferation attributed to cultural attributes. It is therefore one of the underpinning factors contributing to the state of feminization of HIVIAIDS (Kang'ethe, 2014a,b) Cultures have also other ramifications. They also restricts women to own property and to do business without their male spouses' consent (Namatovu, 2012).

Some cultures, especially from traditional African communities indicate that women are inferior to their male counterparts. This sometimes makes men to stop women working or doing business for fear they will be competitive then themselves. In a bid to consolidate their family power, they impoverish or support the processes that dwarf women empowerment generally. Perhaps this is why some cultural researchers are increasingly advocating for a cultural autopsy that will separate progressive from retrogressive aspects of cultures, and also a call for the retrogressive aspects of cultures to be annihilated altogether (Lekoko, 2009; Kang'ethe, 2009, 2014c).

\subsection{Inferiority complex}

Incontrovertible, gender biases, discrimination and unfairness run deep into many countries cultures that do not equate women with men. This is a serious bottleneck towards gender equality and equity and has a serious bearing towards the achievement of countries Millennium Development Goal number three that envisages women empowerment through 
achieving equality and equity with men (Kang'ethe, 2014b). In some countries, female infants are buried alive and tests of the foetus are being done and unborn female foetus with genetic defects are aborted, while unborn male foetus even if they have defects are not aborted (Lopez-Claros and Zahid,2005: 5). Violations of women's rights is seen through acts of forced marriages. Although the trend is dwindling as modernization and the influence of governments towards cultures is increasingly being felt, this has been a characteristic of a few nomadic ethnic groupings in Kenya such as the Turkana, Maasai etc (Kang'ethe 2013b). Also forced marriage still exists due to poverty, ignorance of the communities and little light of development and modernization.

Regrettably, young girls are usually wedded off to elderly men perhaps of the same age as the girls' grandfathers. This is an indication that the life of the girl does not matter or the girl does not have a complete lease of her life as the men themselves who may be in their sunset days of their lives. This phenomenon of wedding of the minors constitutes the highest violations of the rights of women and undermines the rights of the girls to make a choice of their life partners. The girls in most cases are denied the opportunity to pursue their education and their lives blackmailed by their parents and the society at large. These are aspects of underdevelopment and constitutes retrogressive aspects of cultures that need to be annihilated altogether (Kang'ethe, 2014C). The parents of such girls therefore, view their girl children as agents of wealth creation (Kang'ethe, 2013b). The environment of marrying people one never knew or choose also presents a fertile ground for gender based violence and the girl may easily be a victim HIVIAIDS (Kang'ethe, 2009, 2014b).

\subsection{Few women in managerial positions}

Perhaps societal structural socialization has been a bottleneck to the achievement of gender equity and equality. This is because many life institutions appear to have adopted a skewed gender disposition that makes it hard for both men and women to accept fair play and equality between men and women. Perhaps this is why women would tend to vote for men and refuse to empower their fellow women. Although countries such as South Africa declares that there is equal opportunities between men and women and has provision for affirmative action in order to redress any gender imbalances, employment in virtually all the cluntries of the globe suffer some degree of gender bias, with immense bias being a characteristic of most developing countries. For instance, there is uneven and slow progress of women in managerial positions and in meaningful decision making power. A few women in managerial positions find it difficult to balance between career and family. In America, for example, about $49 \%$ of high achieving women are childless as compared to only $19 \%$ of the men population (Lopez-Claros and Zahid, 2005: 4).

Lack of meaningful representation of women at local, regional and international levels show that the decisions are done without the meaningful input of women which in turn results in formulation of policies which inadequately address gender gaps (Ugwuege, 2013). In these researchers' contention, gender gaps will always be there unless men agree to share the burden that women are obliged to handle because of being home makers. For example, a study done in Cameron, Malaysia and Bolivia pointed out that women's income is directed to poverty eradication and social and economic development and improvement of their families unlike some men who spend money on luxurious goods, alcohol and marrying second wives and looking for prostitutes (Lopez-Claros and Zahid, 2005: 4).

\subsection{Resource gap}

Realistically, gender empowerment and in converse disempowerment are linked to resources. A research done by World Bank in 16 developing countries show that the female headed landholdings are usually smaller than men's holdings and in most cases women are less likely to own land (World Bank, 2012). Sixty percent of women are involved in agriculture and they lack land, technology, capital, lack collateral security to access credit facilities from the banks and agricultural extension services (Ugwuege, 2013:195). This mirrors a finding by Musekiwa (2013) that most female headed households immensely suffer the state of feminization of poverty that further also informs the feminization of HIVIAIDS (Musekiwa, 2013).

Women should be empowered through resources. In line with this, the Food and Agriculture Organization of the United Nations postulates that if women equally get access to productive resources as men, their yields could increase by 20 to $30 \%$. This in turn will improve agriculture output in developing countries by $2.5 \%$ to $4 \%$ and this will reduce hunger to nearly 150 million people (Ghanem,2011). This is because women are home makers and are committed to their families and their sustenance more than men. 


\subsection{Domestic Violence}

Domestic violence is still a huge norm especially in countries which are still patriarchal, or where traditionalism, customs are a huge norm. Patriarchy has skewed power relationship between men and women with the results that women are viewed and treated as inferior compared to their male counterparts. This has created a fertile ground for gender based violence (Kang'ethe 2014b; UNDP, 2008). For example, the Centre for Applied Legal Studies (2006) pointed out that about 60\% women in South Africa are abused in their relationships and one women in 35 seconds is raped (Selebogo and Ojakorotu, 2013, 5184). Much efforts have been done to reduce gender gaps world-wide, but gender gaps remain significant especially among the poor and the ignorant.

Perhaps the governments should be blamed for not being serious with gender disparities between men and women as well as boys and the girls. Although countries such as Botswana and Namibia enjoys a perfect gender parity index that means that the girls children have the same opportunity as the boy children in accessing primary education, structural and socialization gender differences dissuade the girl child from competing with the boy children along the development terrain (USAID,2012:6). However, issues of gender development are not taken positively all the time. In some cases, women are abusing the gender policy as a short term investment for grabbing hard won property of their husbands. For example when husband and wife divorce in Zimbabwe, they share the property equally. In such a case, some greedy and lazy women are targeting to marry rich husbands with a hidden agenda of divorcing later so as to gain property in the long run.

\section{Theoretical Framework}

The human rights and the gender analysis approach can be appropriately applied to help in the exploration of gender gaps that impede women's achievement of equality and equity with men. The human rights approach link human rights with gender. Thus if gender equality gaps are to be closed, that would be tantamount to elevating the rights of women and therefore their empowerment. Closing of the gender gaps means for instance fighting against gender based discrimination, gender abuses and atrocities emanating from gender oppression, and making the field of development between men and women level as well as availing resources in equal measures to both men and women. All these have a link to women's enjoyment of their rights and therefore an impetus to their development. This means that there is an inextricable relationship between gender empowerment and acquisition of human rights.. On the other .hand, the gender analysis approach is also appropriate because it advocates for gender equality by influencing society to give equal social and economic opportunities to both men and women. In other words, it is against the discrimination of women and stereotyping of roles in gender.

\section{Way Forward}

\subsection{Mainstreaming gender equality policies}

Appropriate policies can be instrumental in effectuating gender empowerment paradigms. Importantly, all policies should be designed in a way which allows both men and women to enjoy social and economic opportunities in a nondiscriminatory way. To put it differently, all the policies should be gender neutral and gender responsiveness if ever gender gaps are to be closed. It is important that each context is subjected to adequate gender analysis. Also halfhearted policies can never meaningfully fill in the gender gaps which are detrimental to human development. Considering the fact that most women are involved in the production sector, unequal opportunities to access resources as compared to men will lower production process and thereby lowering social and economic development. This can significantly be an impetus of poverty and its other ramifications. Pertinently, all the countries should craft interventions that will increase gender equality and equity, respect of the women and their recognition by all.

\subsection{Women to stand for their rights}

Realistically, women's awareness of their rights is a bold step to realising gender equity and equality. This is because most gender based atrocities are subjected to women because of their ignorance of the law and how to redress the phenomenon. Women need to be challenged to be bold enough to fight for their rights. They need to be supported in their pursuit for gender empowerment. However, sometimes women take too long to internalize the empowerment paradigms on their favour. For example, despite the former President of Botswana increasingly urged women to consider electing 
some of their fellow women, they were hesitant and therefore delayed the women empowerment process. Perhaps these researchers reflect and agree with the contents of the adage that says that one can take a donkey to the river but one cannot force it to drink the water. This is a further challenge to women to pull up their socks and work out for their gender emancipation and liberation. Perhaps this situation of women taking too long to effectuate gender empowerment paradigms can explain why the gender empowerment programmes and policies have not yielded the desirable outcomes, or have taken a snail's pace to bear divindeds

\subsection{Closing the education gap}

Further investment in education in both men and women but especially in women up to university level rather than primary level is likely to bring ripple effects to development. For example educated women are highly likely to contribute better to the family welfare, to the economy, to poverty reduction and will be in a better position to stand for their rights and to participate in politics. In short, education liberates the mind and it is a bold step in the right direction in closing the gender gaps.

\subsection{Women to be united}

Unity is strength, Perhaps women need to learn from this proverb and work round the clock to form an indomitable from through coming together to brainstorm and discuss how to move the gender empowerment processes forward. Unfortunately, women have a mentality condescending the fellow compatriots and rarely want to support one another especially in political dispensation. They rather vote for men instead. Perhaps the socialization of major institutions of life such as the family, schools and other structures may have seriously be influenced by patriarchy making men as well as women see leadership as a function of men and men alone. Perhaps this can be explained by a Setswana proverb that indicates that leadership cannot be effectuated by women, but it is a role of men ( Ga di ke di etelelwa ke managadi pelea herd of cows is never led by a cow, but a bull). Therefore, women with the support of men should prevail upon such attitudes pertaining to their leadership. They should be ready to take the challenge if the gender gaps in many African countries will ever be closed.

\subsection{Culture to be gender equality sensitive}

Though upholding of culture is important, it has to be gender sensitive if the gender gaps are to be closed. Culture and gender equity seems to be two opposing factors. Women are being marginalised in the name of culture. Culture is of great essence in the society, but anti-human rights and anti-women if it is only men centred. Looking at it from that perspective, it becomes oppressive. However, although these researchers' applaud the global top echelon leadership and its commitment to tackling gender empowerment, its high time that countries' socio-cultural terrain is considered when implementing these gender empowerment packages. This is because in Africa, the implementation is not taking cognisance of the cultural dispensation of the societies. This has made gender empowerment to be viewed as a war between men and women, with men thinking they are being undermined by women.

Taking the example of the country of Botswana whose parliament in 2004 made a gender empowerment legislation that dissolved the marital power, the act has made many men in the country feel that the government is pushing the paradigm of women empowerment at the expense of their manhood and their position in the society. Since many men feel they cannot win against women in the event of a conflict, they are increasingly killing women and many a times killing themselves. This brings these researchers to warn the respective governments to tread the route of gender empowerment while taking cognisance of their countries' socio-cultural terrain. To this end, Botswana continues to have higher rates of femicide and passion killing (Kang'ethe, 2009)

\section{Conclusion}

Though gender issues have been recognised across the globe, gender gaps still exists. The policies for gender seem to be half hearted in closing gender gaps. This needs to be cleared through integrating gender equity in all policies in an undicriminatory manner. It is critical for countries to allow full realisation of human rights by allowing both men and women to have equal access to resources, control of resources and equal sharing of benefits. In such a way, there will be meaningful social and economic development. These researchers advocate for a shift from lip service to the practical implementation of gender equality policies if gender gaps are to be closed. 


\section{References}

Barnett, T \& Whiteside, A. (2006). AIDS in the 21st Century. Disease and Globalization. Palgrave. Macmillan.

Botman, R.(2014).Universities' role in the struggle for women's rights. An edited version of Botman's speech at the International Women's Day Conference of the University of Aberdeen in Scotland on 7 March 2014.

Chen, M.(2008). Women and employment in Africa: a framework for action. Harvard University.WIEGO Network

Clinton, H. (2012).Gender Equality and Female empowerment policy.USAID policy. Washington D.C.

Geisler, G (2006). "A second liberation': Lobbying for women's political representation in Zambia, Botswana and Namibia". Journal of Southern African Studies. Vol 32. No1. March 2006.

Ghanem,H.(2011) The State of Food and Agriculture: Women in Agriculture: Closing the Gender Gap for Development. Rome:The Food andAgricultural Organization.

International Labour Organisation (ILO) (2012), Global Employment Trends, Geneva: ILO.

International Labour Organisation. (2008). Global Employment Trends for Youth, October, 2008. Geneva.

Kang'ethe S M (2009). "Inadequate Male involvement in Health Issues: The cause of gender skewed HIVand AIDs situations in Botswana".In: T Maundeni,BZ Osei-Hwedie, E Mukaamambo, PG Ntseane(Eds.): Male Involvement in Sexual and Reproductive Health. Prevention of Violence and HIVIAIDS in Botswana. Cape Town: Made Plain Communications

Kang'ethe, S.M.(2011). Gender discrepancies abound in Community Home Based Care Programme (CHBC) in Botswana. S. Afr. Fam. Pract. 2011.7. Vol 53. No 5. Pg. 467-473

Kang'ethe, S.M. (2013a). Feminization of Poverty in Palliative Care Giving of People

Living with HIV and AIDS and Other Debilitating Diseases in Botswana. Journal of Virology \& Microbiology http://www. Ibimapublishing. com/journals/JVM/jvm.html Vol. 2013 (2013), Article ID 772210, 7 pages. DOI: 10.5171/2013.772210.

Kang'ethe, S.M (2013b). The panacea and perfidy of cultural rites of circumcision in African countries: Examples from Kenya, Botswana and South Africa. EASSRR Journal. Vol. xxix, no 1, pp. 107-123.

Kang'ethe S.M \& Mafa, I. (2014). Dynamics Associated with the Phenomenon of Matrifocality (single motherhood) in Zimbabwe. A literature review. Journal of sociology Soc Anthr 5(2):131-139

Kang'ethe S.M \& Munzara, M. (2014). Exploring an inextricable relationship between feminization of poverty and feminization of HIVIAIDS in Zimbabwe. In the press of Journal of Human Ecology

Kang'ethe S.M. 2014a. Exploring feminization of HIVIAIDS and Millennium Development Goals (MDGs) with examples from Botswana and South Africa. In the press of Journal of Human Ecology.

Kang'ethe, S.M (2014b). The perfidy and Ramifications of gender based violence (GBV) meted against women and the girl children in Botswana. A literature review. In the press of Mediterranean Journal of Social Sciences

Kang'ethe S.M (2014c). Exploring efforts of integrating progressive aspects of cultures into development and purging retrogressive ones from development framework in a score of African countries. In the press of Journal of Human ecology.

Kiriti T \& Tisdel C. (2003). Gender inequality poverty and human development in Kenya. Main Indicators, Trends and Limitations. Working papers of social economics, policy and development. The working paper No.35.University of Queensland

Klugman,J \& Morton,M.(2013).Support versus transformation in development financing: what works to close gender gaps? Journal of International Affairs, Vol. 67(1)

Lekoko RN. (2009).A generation in jeopardy: sexually active women in partriarchal cultural settings and HIVIAIDS. In: Maundeni T, Osei Hwedie BZ, Mukaamambo E, Ntseane PG (eds.) Male involvement in sexual and reproductive health: prevention of violence and HIV/AIDS in Botswana. Made Plain Communications; Cape Town:

Maundeni, Z. (2005). 40 years of Democracy in Botswana. 1965-2005. Mmegi Publishing House, Gaborone.

Mupfeka, L.(2008). Participation of rural women in local governance in Murewa district, Zimbabwe: women walking political paths. A Dissertation submitted in partial fulfilment of the requirements for the Masters Degree in Women's Law, Southern and Eastern African Regional Centre for Women's Law, Faculty of Law, University of Zimbabwe

Musekiwa, P (2013).Livelihood Strategies of Female-Headed Households in Zimbabwe. The case of Magaso Village, Mutoko District. Unpublished Masters of Social Work Dissertation. Social work department, Faculty of Social Sciences, University of Fort Hare

Namatovu (2012). Gender and Investment: Impact of the EAC Integration process on Cross Border Investment: A Case Study of Women Investors in the EAC Region. PEDL

Pizarro, D \& Bartels, D. (2011). The mismeasure of morals: Antisocial personality traits predict utilitarian responses to moral dilemmas. Cognition 2011.Columbia University. New York.

Ramphele M (2008). Laying Ghosts to Rest. Dilemmas of the Transformation in South Africa. Cape Town

Reeves,H \& Baden,S. (2000).Gender and Development: Concepts and Definitions. Report 55) Institute of Development Studies. University of Sussex. BRIDGE (development - gender)

Ricardo,H. Tyson, L\& Zahidi,S. (2012) Global Gender Gap Report 2012. World Economic Forum. Geneva, Switzerland: World Economic Forum, 59

Selebogo,M.Y.P.(2013).SADC Gender and Development Protocol: An Evaluation of Equality, Empowerment and Gender Based Violence in South Africa (2008-2012).Journal of gender and behaviour.Vol.11(1)

Shepherd, J (2002). Sociology.Belmont, CA: Wadsworth: Thompson learning.

South African Development cooperation (SADC) (2008) Gender protocol. Southern African Development Community. Towards common Future, Johannesburg: SADC 
The World Bank, World Development Report (2012):Gender Equality and Development, Washington,DC: TheWorldBank

Ugwueje,E.A (2013).Gender quality mainstreaming: Implications for poverty Reduction and Sustainable development in Abia state of Nigeria. Critique of millennium development goals in Third world Development Strategies. Decades of Fascinations and Frustrations. Verity publishers. Pretoria.

United Nations Development Plan (2008). Situation Analysis on Gender Based Violence in Botswana. Draft Report. Participatory Education, Evaluation and Research. Gaborone

United Nations Development Plan (2004). Botswana Millennium Development Goals. Achievement, Future Challenges and choices. United Nations, Republic of Botswana

United Nations Development Programme (1998a). Human Development Report, New York: Oxford University Press. United Nations Development Programme (1998b). Overcoming Human Poverty, New York: Oxford University Press.

UN-ESCWA Main Indicators, Trends and Limitations.(2009) Promoting the economic participation of Arab women 